\title{
ON EVIDENCE AND BELIEF
}

\author{
SOBRE EUIDENCLA Y CREENCLA
}

Marco Antonio Joven-Romero

\begin{abstract}
In this article I analyse how evidence influences, determines and evaluates belief formation. I deal with the main normative accounts and with constitutive nonnormative accounts of the evidential thesis for belief emergence and I finally defend that evidentialism must be understood in constitutive non-normative terms. More specifically, evidentialism must be based on the idea that believers always consider that they have enough evidence for their beliefs.
\end{abstract}

KEYWORDS: Normativity, evidentialism, reasons for belief, wishful thinking, belief emergence.

\section{RESUMEN}

En este artículo analizo cómo la evidencia influye, determina y evalúa la formación de la creencia. Trato las principales visiones normativas y constitutivas no normativas sobre la tesis evidencialista para la emergencia de creencias y finalmente defiendo que el evidencialismo debe ser entendido en términos constitutivos no normativos. Más específicamente, el evidencialismo debe basarse en la idea de que los creyentes siempre consideran que tienen suficiente evidencia para sus creencias.

PALABRAS CLAVE: Normatividad, evidencialismo, razones para la creencia, wishful thinking, creación de las creencias.

\section{INTRODUCTION}

Evidentialist philosophers defend that evidence is mandatory for belief formation (Whiting 2014, Adler \& Hicks) while non-evidentialist philosophers support that sometimes beliefs may emerge without the need of evidence (Reisner, Rinard). Evidentialists usually defend that evidence is the only reason for belief emergence: agents form beliefs because they receive evidential in-puts. Non- 
evidentialists usually admit a broader range of possibilities. What I here call the evidentialist thesis establishes that evidence is a necessary reason for belief formation. The amount and quality of evidence sufficient to develop beliefs are other hot spots of the debate.

In this work I analyse what evidentialism for belief emergence means. However, I do not adopt any specific position on the evidentialism vs. non-evidentialism debate. For that, in section $2 \mathrm{I}$ deal with the main normative approaches to evidentialism - believers should believe $p$ if and only if there is (enough) evidence to believe $p$ - and I argue that an evaluative normative characterization of evidentialism may allow for "incorrect" non-evidential reasons for belief emergence, something that a pure evidentialist position does not allow. In section 3 I deal with the main non-normative account of evidentialism - believers believe $p$ if and only if there is (enough) evidence to believe $p$. I argue that a constitutive non-normative characterization of evidentialism does not allow for beliefs emerged according to non-evidential reasons, but at the same time it may admit different standard of correctness to judge already formed beliefs. In section 4 I finally defend that the evidentialist position must be described in constitutive non-normative terms according to a minimum amount of evidence as the reason for belief formation. Such minimum amount of evidence is established by the very believer: believers believe $p$ if and only if believers consider that they have enough evidence to believe $p$. Finally, in section 5 I sum up this work.

To exemplify the different approaches I focus on wishful thinking cases, which are usually labelled as beliefs. Wishful thinking cases are very suggesting for this analysis, as they work as beliefs based or emerged according to weak or no evidence. More specifically, I continuously refer to the James' love case:

(James' love case) James is in love with Olga and he is convinced that it is a requited love. Olga does not love James, and she tells him. Furthermore, James' friends try to convince him showing opposite evidence and James has himself seen Olga dating another boy many times. But it does not matter: for James, Olga is just playing hardball with him. James believes Olga loves him too.

In this case, James develop his belief against the most reliable available evidence given by his friends and by Olga herself. Broadly put, pure evidentialist philosophers defend that James developed his false belief due to - defectiveevidence even if other conative or pragmatic features may have influenced such belief emergence. Normative evidentialist philosophers focus on the incorrectness 
of James' belief. Non-evidentialist philosophers may say that in some cases, like the James' love case, beliefs may emerge without any evidential reason.

Other similar wishful thinking cases are the football team supporter who believes that his team is going to win the next match although most of the available and reliable evidence shows the opposite, or the mother of a criminal who believes that her son is innocent despite the fact that most available and reliable evidence shows the opposite.

\section{Normative ACCOUNTS OF THE EVIDENTIALIST THESIS}

(i) For an agent $S$ and a proposition $p, S$ should believe $p$ if and only if there is evidence to believe $p$.

This is the most demanding account for the defence of evidential reasons for belief formation. First, the implication if there is evidence to believe $p$, then $S$ should believe $p$ ' forces the agent to develop beliefs for every available piece of evidence. But many pieces of evidence are continuously available, the agent is not able to continuously develop the correspondent beliefs and sometimes pieces of evidence are contradictory.

Second, the implication 'if $S$ should believe $p$, then there is evidence to believe $p^{\prime 1}$ establishes an epistemic standard of correctness for beliefs - they are correct only if there is evidence to believe them- but it is far from clear that beliefs may be evaluated only according to epistemic terms. And, as said before, there can be contradictory evidence when developing a specific belief. In the James' love case,

1 If preferred, ' $S$ should believe $p$ only if there is evidence to believe $p$ ' or 'if there is not any evidence to believe $p$, then $S$ should not believe $p$ '.

It should be noted that in a broad sense, the latter implication is that if there is not any evidence to believe $p$, then it it not the case that $S$ should believe $p$ '. But this broad scope allows for correct beliefs based on no evidence, something that is not permissible from the normativist evidentialist thesis of beliefs. For that reason I state a narrow scope of the implication: 'if there is not any evidence to believe $p$, then $S$ should not believe $p^{\prime}$.

Following Daniel Whiting (2010, 2013a, 2013b, 2014), another possible norm for the evidential thesis on beliefs is that ' $S$ may believe $p$ if and only if there is evidence to believe $p$ '. In that way, 'if there is not evidence to believe $p$, then it is not the case that $S$ may believe $p$, so $S$ should not believe $p^{\prime}$. At the same time, this normative account solves the problem of developing beliefs for every available piece of evidence: 'if there is evidence to believe $p$, then $S$ may believe $p$, but she is not forced to do so'. On the contrary, this account does not tell how and when evidence enhances belief formation. It just states possibility conditions for belief emergence. 
there is evidence to believe that Olga does not love James, then James should believe that Olga does not love him. But he does believe that Olga loves him, contrary to the most reliable evidence, and even if the belief is epistemically incorrect, it may psychologically aid James.

The second implication of this account establishes that if there is not any evidence to believe that Olga loves James, then James should not believe that Olga loves him (see footnote 1). But he does believe that Olga loves him, apparently with no evidence.

It may be argued that James' belief that Olga loves him is incorrect — James should not believe so and he should believe that Olga does not love him. But such incorrectness is just epistemic. According to other standards of correctness, James' belief may be correct - e.g. it provides emotional fitness to him, at least in the short run, and this may be useful for him. Moreover, for the evidentialist thesis evidence must be a reason for belief emergence. And in the James' love case, there is a false belief developed against the most reliable evidence. I will go further this issue in sections 3 and 4 .

One possible reformulation of the normative account of the evidential thesis for belief formation to solve some of the previous problems may specify the amount of evidence the agent needs to develop her belief:

(ii) For an agent $S$ and a proposition $p, S$ should believe $p$ if and only if there is enough evidence to believe $p$.

First, the implication 'if there is enough evidence to believe $p$, then $S$ should believe $p$ ' forces the agent to develop beliefs if there is enough evidence available. It solves the problem of continuously developing beliefs for every available piece of evidence the previous formulation had. Nevertheless, it does not specify how much evidence the agent needs to develop her belief. I will further this issue in section 4.

Second, the implication if $S$ should believe $p$, then there is enough evidence to believe $p^{2}$ also establishes an epistemic standard of correctness for beliefs they are correct only if there is enough evidence to believe $p$ - but once again it is far from clear that beliefs may be evaluated only in epistemic terms.

2 If preferred, ' $S$ should believe $p$ only if there is enough evidence to believe $p$ ' or 'if there is not enough evidence to believe $p$, then $S$ should not believe $p$ '. See also footnote 1 . 
If we apply this normative account of the evidentialist thesis for belief emergence to the James' love case, first we have that James should believe that Olga does not love him if there is enough evidence to believe that Olga does not love James. Actually James' friends and Olga herself tell him that she does not love him and James has himself seen Olga dating another guy many times. So it can be thought that James really has enough evidence to develop the belief that Olga does not love him. But he does believe that Olga loves him, contrary to what is likely to be taken as enough evidence.

Second, if there is not enough evidence to believe that Olga loves James, then James should not believe that Olga loves him (see footnote 1). But he does believe that Olga loves him, apparently without having enough available evidence. And once again, James' belief that Olga loves him is correct from an epistemic perspective, but it may be correct from other non-epistemic perspectives.

In short, normative accounts of evidentialism on beliefs present some problems. First, they may force agents to form beliefs for every available piece of evidence (i), but this problem can be solved if the amount of evidence needed for belief emergence is specified. I reformulate the primitive normative account tingeing that enough evidence is needed for belief emergence (ii) and in section 4 I will specify how much evidence is "enough". Second, normative accounts judge beliefs only according to epistemic terms, but it may be argued that other standards of correctness are also adequate to judge beliefs - i.e. some false beliefs may be correct beliefs for non-epistemic standards of correctness. Third, these normative accounts admit the possibility of beliefs emerged following no evidence even if they are incorrect — these beliefs are just negatively judged-, and this is far from a pure evidentialist thesis for belief emergence that states that evidence is a necessary reason to develop beliefs.

\section{NON-NORMATIVE ACCOUNTS OF THE EVIDENTIALIST THESIS}

Non-normative accounts of the evidentialist thesis are broader than the previous normative ones. They do not pose any strict norm - should- on the relationship between belief and evidence, but they just establish that such relationship is constitutive. In that way, they may admit non-epistemic standard of correctness on beliefs but they refuse the possibility of beliefs emerging following no evidence.

(iii) For an agent $S$ and a proposition $p, S$ believes $p$ if and only if there is evidence to believe $p$. 
First, the implication 'if there is evidence to believe $p$, then $S$ believes $p$ ' establishes that agents develop beliefs for every available piece of evidence. But agents continuously have many available pieces of evidence and they do not form beliefs for all of them. Furthermore, sometimes these pieces of evidence are contradictory.

Second, the implication 'if S believes $p$, then there is evidence to believe $p^{3}$ refuses the possibility of forming any belief following no evidence. Nevertheless, such refusal is far from clear and sometimes there may be contradictory evidence when developing beliefs.

In the James' love case, first James has evidence to believe that Olga does not love him - friends' testimonies, James has seen Olga dating another guy many times, Olga told James that she does not love him- but James does not believe that Olga does not love him. Actually James believes that Olga loves him. This is against this account of evidentialism on beliefs, and the only way of solving this issue is to consider that James has contrary more powerful evidence to believe that Olga loves him.

Second, if James has no evidence to believe that Olga loves him, then he does not believe that Olga loves him. But he does believe that Olga loves him. So the only way to accommodate James' love case to this characterization of the evidential thesis for belief formation is to consider that James has evidence to believe that Olga loves him.

As with the previous normative accounts, a possible reformulation of this constitutive account of the evidential thesis for belief emergence to solve some of these problems may specify the amount of evidence the agent needs to develop her belief:

(iv) For an agent $S$ and a proposition $p, S$ believes $p$ if and only if there is enough evidence to believe $p$.

First, the implication 'if there is enough evidence to believe $p$, then $S$ believes $p$ ' establishes that the agent develops her beliefs if there is enough available evidence. It solves the previous problem of developing beliefs for every available piece of evidence. But it does not clarify how much evidence is needed to develop beliefs. As I said before, I will further this issue in the next section.

3 If preferred, ' $S$ believes $p$ only if there is evidence to believe $p$ ' or 'If there is not any evidence to believe $p$, then $S$ does not believe $p$ '. 
Second, the implication if $S$ believes $p$, then there is enough evidence to believe $p^{4}$ refuses any belief formed without a minimum amount of evidence. But once again it is far from clear that all beliefs are formed following such a minimum amount of evidence and sometimes there is contradictory evidence for belief emergence.

In the James' love case, first James seems to have enough evidence to believe that Olga does not love him — friends' testimonies, James has seen Olga dating another guy many times, Olga told James that she does not love him-, but James does not believe that Olga does not love him. James currently believes that Olga loves him. This seems to be against this account of evidentialism on beliefs. The only way of solving this issue from this account is to consider that James has a greater amount of contrary evidence to believe that Olga loves him.

Second, if James does not have enough evidence to believe that Olga loves him, then he does not believe that Olga loves him. But he does believe that Olga loves him. So once again the only way to accommodate this characterization of the evidential thesis on beliefs is to consider that James has enough evidence to believe that Olga loves him.

In conclusion, these non-normative accounts of evidentialism for belief emergence also present problems. First, and similar to the normative accounts, they establish that every available piece of evidence forms beliefs (iii), but once again this problem can be solved if the amount of evidence needed for belief formation is specified. For that, I reformulate the primitive normative account stating that "enough evidence" is needed for belief emergence (iv). In the next section I will specify how much evidence is "enough". Second, non-normative accounts may admit any standard of correctness for the evaluation of beliefs. So they admit that a false belief may be correct in non-epistemic terms. What they state is that such false belief necessarily emerges due to evidence. So third, and contrary to the normative accounts of the evidential thesis for belief emergence, these constitutive non-normative approaches deny the possibility of beliefs following no evidence. For instance, James' false belief that Olga loves him may be positively judged in terms of pragmatic standards of correctness and negatively judged in terms of epistemic standards of correctness, but James must have formed it following defective evidence — but evidence.

\footnotetext{
4 If preferred, ' $S$ believes $p$ only if there is enough evidence to believe $p$ ' or 'If there is not enough evidence to believe $p$, then $S$ does not believe $p$ '.
} 


\section{A PROPOSAL FOR THE EVIDENTIALIST THESIS FOR BELIEF EMERGENCE: BELIEVERS CONSIDER THAT THEY HAVE ENOUGH EVIDENCE FOR THEIR BELIEFS}

Finally, I defend that the most plausible approach to characterize the evidentialist thesis for belief emergence derives from (iv): for an agent $S$ and a proposition $p, S$ believes $p$ if and only if there is enough evidence to believe $p$.

In that way, I support a constitutive treatment of evidentialism on beliefs. A normative evaluative treatment of evidentialism may also be stated, but this is far from my purposes. I actually admit that non-epistemic standards of correctness may also evaluate beliefs, but a pure and basic evidential approach to belief must be constitutive of belief. The evidential thesis must be based on the idea that evidence is mandatory to form beliefs, even if these beliefs are false and the evidence is defective ${ }^{5}$.

The problem is now to state how much evidence is sufficient to form beliefs i.e. how much evidence can be considered "enough" for belief emergence. And the solution I propose relies on the believer's attitude: evidence is enough if and only if the believer considers it to be enough. More specifically, the reformulation I propose to deal with and clarify the evidential thesis for belief emergence is the following one:

(v) For an agent $S$ and a proposition $p, S$ believes $p$ if and only if $S$ considers that she has enough evidence to believe $p$.

First, the sufficient condition 'if $S$ considers that she has enough evidence to believe $p$, then $S$ believes $p$ ' establishes that the agent develops her beliefs if she considers that there is enough available evidence. Agents do not develop beliefs for every available piece of evidence but they need to consider such pieces enough to form beliefs. Second, the necessary condition if S believes $p$, then S considers that she has enough evidence to believe $p^{3}$ refuses any belief formed without what $S$ considers to be enough evidence.

In the James' love case, this treatment of the evidential thesis establishes that James considers that he has enough evidence to believe that Olga loves him — in

\footnotetext{
${ }^{5}$ Note that here I do not want to defend evidentialism. I just want to state an accurate definition and treatment of the evidentialist thesis.

${ }^{6}$ If preferred, ' $S$ believes $p$ only if S considers that she has enough evidence to believe $p$ ' or 'if $S$ does not consider that she has not enough evidence to believe $p$, then $S$ does not believe $p$ '.
} 
spite of his friends' testimonies, in spite of seeing Olga dating another guy many times, in spite of Olga's confession that she does not love him-, so then Jimmy believes that Olga loves him. What James considers to be enough evidence is weak or poor evidence that is likely to be infected by conative facts, but it is still evidence. On the contrary, James' friends develop their belief that Olga does not love James in terms of what they consider to be more reliable evidence - enough for them. If James considers the evidence provided by his friends to be enough to believe that Olga does not love him, then James would believe that Olga does not love him.

Second, if James does not consider his personal evidence enough to believe that Olga loves him, then James would not believe that Olga loves him. But he does believe that Olga loves him because he really considers that his personal evidence is enough. Similarly, if James' friends do not consider their personal evidence enough to believe that Olga does not love James, then they would not believe that Olga does not love James, but they do because they consider their evidence to be enough.

It may be argued that more feasible and suitable evidence must prevail when forming beliefs and acting in an opposite manner is just a symptom of mental illness. Nevertheless, wishful thinking and similar beliefs are rather common. As previously said, a football team supporter who believes that his team is going to win the next match against the best team at present or the mother of a criminal who believes in her son's innocence are some examples. Lottery players under the belief that they are going to win the lottery with no strong empirical basis are frequent. Under a constitutive evidentialist thesis, these agents form their beliefs according to some kind of evidence. I defend that in a broader and accurate characterization of constitutive evidentialism these agents consider their evidence to be enough and that is not necessarily a sign of mental illness. These agents may select defective evidence and may consider it to be enough due to non-epistemic features - eg. conative or pragmatic issues- but that is not against to what I consider the best characterization for a constitutive evidentialist thesis on belief: believers always have evidence for their beliefs and they consider such evidence to be enough.

\section{Conclusions}

After the analysis of the main normative and non-normative characterizations of the evidentialist thesis for belief emergence, I finally defend a non-normative one based on the idea that the minimum amount of evidence needed for belief 
formation is determined by the very believer. In that way, I establish that a correct characterization of evidentialism for belief formation must not focus on the establishment of epistemic standard of correctness but it must defend and describe the constitutive relationship between the believer, belief formation and evidence. Actually, I am not against the idea that different non-epistemic standard of correctness may judge beliefs and at the same time I admit that epistemic standard of correctness may also judge belief formation. However, what really defines evidentialism is the believer's commitment to a minimum of evidence: this commitment works as a necessary and sufficient reason for belief emergence.

It must be noted that here I do not want to defend evidentialism, but just help to clarify how we should consider and analyse the evidentialist thesis for belief emergence. I do not take a position on the reasons for the emergence of James' belief that Olga loves him. I only state that, from an evidentialist position, it must be defended that James considers that he has enough evidence to believe that Olga loves him.

\author{
Marco Antonio Joven-Romero \\ AECID, UNED, University of Santo Tomas (Manila) \\ majovenromero@ust.edu.ph
}

\title{
REFERENCES
}

Adler, J. \& Hicks, M. (2013): "Non-Evidential Reasons to Believe", in Timothy Chan (Ed.), The Aim of Belief, Oxford: Oxford University Press, pp. 140-166.

Reisner, A. (2013): "Leaps of Knowledge", in Timothy Chan (Ed.), The Aim of Belief, Oxford: Oxford University Press, pp. 167-183.

Rinard, S. (2015): “Against the New Evidentialists", Pbilosophical Issues, no 25(1), pp. 208-223. Whiting, D. (2010): “Should I Believe the Truth?”, Dialectica, no 61, pp. 213-224.

Whiting, D. (2013a): "Truth: the Aim and Norm of Belief”, Teorema: Revista Internacional de Filosofía, no 32(3), pp. 121-135.

Whiting, D. (2013b): "Nothing But The Truth: On the Norms and Aims of Belief", In Timothy Chan (Ed.) The Aim of Belief, Oxford: Oxford University Press, pp. 184-202. Whiting, D. 2014): "Reasons for Belief, Reasons for Action, the Aim of Belief, and the Aim of Action", en Clayton Littlejohn and John Turri (eds.), Epistemic Norms. New Essays of Action, Belief, and Assertion, Oxford: Oxford University Press, pp. 219-237. 